\title{
Gian Cristoforo Romano in Rome: With some thoughts on the Mausoleum of Halicarnassus and the Tomb of Julius II
}

\author{
SALLY HICKSON
}

University of Guelph

En 1505, Michel-Ange est appelé à Rome pour travailler sur le tombeau monumental du pape Jules II. Six mois plus tard, alors que Michel-Ange se trouvait à Carrare, le sculpteur et antiquaire Gian Cristoforo Romano était également appelé à Rome par Jules II. En juin 1506, un agent de la cour de Mantoue rapportait que les « premiers sculpteurs de Rome », Michel-Ange et Gian Cristoforo Romano, avaient été appelés ensemble à Rome afin d'inspecter et d'authentifier le Laocoön, récemment découvert. Que faisait Gian Cristoforo à Rome, et que faisait-il avec Michel-Ange? Pourquoi a-t-il été appelé spécifiquement pour authentifier une statue de Rhodes. Cet essai propose l'hypothèse que Gian Cristoforo a été appelé à Rome par le pape probablement pour contribuer aux plans de son tombeau, étant donné qu' il avait travaillé sur des tombeaux monumentaux à Pavie et Crémone, avait voyagé dans le Levant et vu les ruines du Mausolée d'Halicarnasse, et qu'il était un sculpteur et un expert en antiquités reconnu. De plus, cette hypothèse renforce l'appartenance du développement du tombeau de Jules II dans le contexte antiquaire de la Rome papale de ce temps, et montre, comme Cammy Brothers l'a avancé dans son étude des dessins architecturaux de Michel-Ange (2008), que les idées de ce dernier étaient influencées par la tradition et par ses contacts avec ses collègues artistes.

$\mathrm{O}$ n July 30, 1505 Gian Cristoforo Romano (1456-1512) — sculptor, medalist, antiquarian, and courtier - wrote to Isabella d'Este in Mantua to inform her that he had been called to Rome by Pope Julius II. ${ }^{1}$ The summons came just six months after Michelangelo had arrived in the city, corresponding, in fact, to the period just before the Florentine departed for Carrara to select marble for the Pope's tomb. ${ }^{2}$ By 1506, Donato Bramante was in Rome planning the new St. Peter's, and the Milanese goldsmith and medalist Caradosso Foppa was also in the city, perhaps already working on the famous portrait medal of Julius II with the projected façade for Bramante's new church on its reverse. ${ }^{3}$ On 18 April 1506, while Gian Cristoforo was still in Rome, the foundation stone of St. Peter's was laid by Julius II. 
The 1505 papal summons arrived when Gian Cristoforo was in Milan working on the design for an arca, or tomb, that Isabella d'Este had commissioned to honour the recently deceased Beata Osanna Andreasi of Mantua (d.1505). Although the Andreasi monument was to be installed in a church in Mantua, Gian Cristoforo created the design while in Milan, where he conferred with Osanna's official biographer, Fra Silvestri, who reported regularly to Isabella about progress on the monument. ${ }^{4} \mathrm{At}$ the Pope's direct request, then, Gian Cristoforo was among the first wave of artists called to effect the classical revival crucial to the stabilization and glorification of the new reign of Julius II and the Roman church triumphant.

Although we know about his summons by the Pope, it is not clear exactly what Gian Cristoforo was called to the city to do. Although he was eventually charged with working on the Pope's project to renew the sanctuary of the Santa Casa at Loreto, where he died in 1512, he did not go there until 1508 or 1509. We know that in 1506 he made a portrait medal to honour Julius II, but he does not reappear in the papal account books until 1509 when he was paid for two more medals celebrating Julian expansion in Rome and Civitavecchia. ${ }^{5}$ Although Castiglione's Courtier places him in Urbino in 1508, we know from other documents that he was in Naples before that. In late 1509 Gian Cristoforo left Rome with Bramante to work on the Santa Casa in Loreto, and he is documented there continuously in the last two years of his life, from $1510-2 .{ }^{6}$ Since by this time he had spent the better part of four years in Rome, it seems worth asking again what exactly he might have been doing there. ${ }^{7}$

Of course, he was originally from Rome, thus the appellation "Romano." His father, the sculptor Isaia of Pisa, died when Gian Cristoforo was still a child and was therefore probably not responsible for his training. Instead, art historians speculate that Gian Cristoforo studied with Andrea Bregno (d.1506). ${ }^{8}$ Bregno came from a successful workshop of sculptors in northern Italy and, after being invited to Rome by Sixtus IV, became the most important designer of funerary monuments of his age, contributing to the redesign of the church of Santa Maria del Popolo, which would eventually house a number of important della Rovere tombs. ${ }^{9}$ In 1504, Julius II summoned Andrea Sansovino from Florence and put him to work on other tomb monuments in Santa Maria del Popolo, specifically the memorials to Cardinal Ascanio Maria Sforza (d.1505) and Cardinal Girolamo della Rovere (d.1507). ${ }^{10}$ By continuing the patronage of his uncle Sixtus IV in Santa Maria del Popolo, Julius exemplified the same spirit of dynastic, papal continuity he brought to his patronage of the Sistine Chapel. Of course, such patronage also put him in touch with the most avant-garde designers of funerary monuments available in Rome. 
In the 148 os, following his apprenticeship with Bregno in Rome, Gian Cristoforo was in Urbino and Ferrara; by 1490 he was in Milan, where he worked on his first major project in 1494-5, contributing to the sculptural decoration of the grandiose tomb of Giangaleazzo Visconti at the Certosa in Pavia (with Benedetto Briosco, see illustration 1). ${ }^{11}$ At court, he supplied the Duchess Beatrice d'Este with a portrait bust that was very much admired by her sister, Isabella d'Este, and he also continued to work on larger-scale sculptural projects. For example, he designed a tomb for Pier Francesco Trecchi in the church of Sant'Agata in Cremona, notable because it is made completely of Carrara marble. ${ }^{12}$ In 1496 , when the court of Milan was occupied by the French King Louis XII, Gian Cristoforo, like many other artists, was forced to seek patronage elsewhere and found refuge in Mantua working full-time for Isabella d'Este, presumably on her sister's recommendation.

Isabella was one of the most distinguished collectors and patrons of the age, responsible for creating new standards of splendour in the accumulation and display of antiquities. In her Grotta, her private museum of antiquities, she delighted in displaying antique cameos, bronzes, and small marble statues which she displayed next to their modern all'antica counterparts. This spirit of classical revival was evoked in the famous allegorical paintings she commissioned from Andrea Mantegna, Pietro Perugino, and others to adorn her private humanist study. ${ }^{13}$ Aside from work on medals and portrait busts, Gian Cristoforo's major undertaking for Isabella was the design and execution of exquisitely carved architectural fittings for her Grotta and studiolo, such as the famous multi-coloured marble doorframe with its classical allusions to musical harmony intended to reflect the intellectual harmony of Isabella's rooms. ${ }^{14}$ In addition to his work as a sculptor, Gian Cristoforo's most important role in Mantua was as the trusted consultant to Isabella regarding her acquisition of antiquities, a subject on which he was regarded by contemporaries as an expert. In Mantua he was rated second only to Mantegna in terms of his antiquarian expertise. ${ }^{15} \mathrm{He}$ was well-respected among his contemporaries and makes an appearance in several literary works, most significantly appearing as an interlocutor in the first book of Castiglione's Courtier, where he defends the superiority of sculpture over painting. ${ }^{16}$

While Gian Cristoforo was celebrated by his contemporaries as a talented and well-mannered courtier, and as a sculptor, medalist, and antiquarian, it is also important to remember that, by dint of experience, he was a very experienced and talented expert when it came to the planning and execution of tomb monuments. The papal summons came, in fact, when he was in Milan designing the tomb of the Beata Osanna. It is possible that it was this skill that particularly qualified him for 
a papal summons at precisely the time that Julius II was set on building the new St. Peter's and laying plans for his own papal tomb.

\section{The Tomb of Julius II}

Michelangelo's original plans for the Julius tomb have long been a source of debate among art historians. ${ }^{17}$ Most of our ideas about the original structure are based on the description written by Ascanio Condivi in his Life of Michelangelo (published in 1553) where he memorably characterized Michelangelo's ultimate failure to build the tomb — as he had envisioned it — to be the central tragedy of his career. ${ }^{18}$ Condivi was a minor workshop assistant to whom Michelangelo seems to have virtually dictated his biography, so it is surprising that the tomb description, which must have been supplied by Michelangelo himself, is so confused and difficult to visualize. Part of the problem must certainly have been that Condivi was writing retrospectively about a plan that had changed several times since Michelangelo first conceived it in 1505. Condivi writes:

E per darne qualche saggio, brevemente dico che questa sepoltura doveva aver quattro facce: due di braccia diciotto, che servivano per fianchi; e due di dodici, per teste, talché veniva ad essere un quadro e mezzo. Intorno intorno di fuore erano nicchia, termini, ai quali, sopra certi dadi che movendosi da terra sporgevano in fuori, erano altre statue legate come prigioni, le quali rappresentavano l'arti liberali, similmente pittura, scultura e architettura, ognuna colle sue note, sicché facilmente potesse esser conosciuta per quel che era; denotando per queste, insieme con papa Giulio, esser prigioni della morte tutte le virtù, come quelle che non fossero mai per trovare da chi cotanto fossero favorite e nutrite, quanto da lui. Sopra queste correva una cornice, che intorno legava tutta l'opera, nel cui piano eran quattro grandi statue, una delle quali; cioè il Moisè, si vede in San Pietro ad Vincula, e di questa si parlerà al suo luogo. Così ascendendo l'opera, si finiva in un piano, sopra il quale erano due agnoli che sostenevano un'arca: uno d'essi faceva sembiante di ridere, come quello che si rallegrasse che l'anima del papa fosse tra gli beati spiriti ricevuta; l'altro di piangere, come se si dolesse che ' 1 mondo fosse d'un tal uomo spogliato. Per una delle testate, cioè per quella che era dalla banda di sopra, s'entrava dentro alla sepoltura in una stanzetta, a guisa d'un marmo, dove si doveva seppellire il corpo del papa: ogni cosa lavorata con maraviglioso artificio. Brevemente, in tutta l'opera andavano sopra quaranta statue, senza le storie di mezzo rilievo fatte di bronzo, tutte a proposito di tal caso, e dove si poteva vedere i fatti di tanto pontefice. ${ }^{19}$

The full description is important, I think, because its ambiguity has prompted art and architectural historians to read it in various ways. Condivi describes a 
two-storey free-standing mausoleum, copiously decorated with sculpture and capped with some kind of catafalque or sarcophagus. This structure would contain and enframe an open, centralized space, described by Condivi as a kind of tempietto that would be used to house a marble chest containing the pope's body. Both Condivi and Vasari, who changed his original 1550 account of the tomb in the 1568 edition of the Lives to better reflect Condivi's description, described the proposed sculptural program which would celebrate Julius as a patron of the liberal arts. While the over-arching theme of the iconographical program is clear, there is less agreement about Michelangelo's intentions for the structure of the tomb. The situation is made more difficult because we have few early drawings by Michelangelo that help to elucidate the original plan.

In his examination of the corpus of Michelangelo drawings, Michael Hirst identified a drawing, now in the Metropolitan Museum of New York, which he concluded demonstrates Michelangelo's earliest thoughts about the tomb in $1505 .{ }^{20}$ Cammy Brothers, who has recently examined Michelangelo's drawings precisely in the context of the evolution of his architectural thought, agrees that the New York drawing shows Michelangelo's original plan. ${ }^{21}$ The drawing shows the narrow end bay of what appears to be a monumental structure of two levels, a central arch containing the semi-reclining effigy of the pope supported by angels, and upper and lower stories consisting architecturally of superimposed pilasters which frame numerous standing and seated sculptures. Just after Julius died in 1513, Michelangelo was hired by his heirs to continue the tomb, and Hirst and Brothers agree that the description Condivi gives probably reflects this second plan, as found in a drawing copied from Michelangelo's 1513 plan by Giacomo Rocchetti (now in Berlin) and in a drawing by Michelangelo himself (now in the Uffizi) which gives a partial view of his ideas for the lower storey. ${ }^{22}$ In this second conception, the tomb is a much more monumental structure, the central arch soaring above the lower storey, and many of the sculptures seem to be independent of the frame of the architecture. Here the writhing slaves actually seem to move to obscure many of the applied pilasters. All of the drawings are elevations that depict one side of the four unequal sides that Condivi describes, and all allude to a three-dimensional structure. Comparing the drawings, Brothers has demonstrated that Michelangelo made certain modifications to the tomb plan between 1505 and 1513, fundamentally changing the width and rhythm of the bays and making the figures considerably less restrained, changes that transformed what was originally a much more traditional and sober classicizing tomb into a structure that would have fairly seethed with dynamic and dramatic figures. ${ }^{23}$ What did not change, however, was the idea of creating a free-standing mausoleum structure on a 
monumental scale, the likes of which had not been seen since antiquity. It was only later, in 1545, that the final structure was "compromised" and completed as the wall tomb that is now found in San Pietro in Vincoli (Illustration 2). ${ }^{24}$

Art and architectural historians have wondered about the origin of this freestanding mausoleum plan. Some have suggested that the idea originated with Julius himself, who wanted a monument that echoed the imperial tombs he saw in Rome. Alfred Frazer suggested that Michelangelo based his original design on ancient coins that depicted imperial tombs as well as temporary columnar funeral pyres that some Renaissance antiquarians mistook for permanent mausolea. ${ }^{25}$ Art historians have also cited more immediate architectural precedents such as Alberti's Rucellai Chapel in Florence and Andrea Sansovino's tomb monument to Cardinal Ascanio Sforza in Santa Maria del Popolo, both of which were free-standing monuments. ${ }^{26}$

Many years ago, however, Christoph Frommel suggested that the initial design for Julius's tomb was modeled on the Mausoleum of Halicarnassus. ${ }^{27}$ One of the difficulties with this proposal has been in finding any direct link between the mausoleum, the plan for the Julian tomb, and Michelangelo. Based on the evidence I will now present, one source for information about the Mausoleum of Halicarnassus was surely Gian Cristoforo Romano. Gian Cristoforo had traveled to the Levant, had expertise in tomb design, and was, as we have seen, called to Rome by Julius at exactly the time he was planning his tomb. Furthermore, as described below, he was directly linked with Michelangelo by contemporaries, who reported that in 1506, at the Pope's request, he had accompanied Michelangelo to inspect the recently unearthed statue of the Laocoön. In order to examine the possibility that Gian Cristoforo played a role in disseminating information about the Mausoleum in Roman circles, information that might well have informed Julius's conception of the tomb and might even have had some influence on Michelangelo's thoughts in the initial planning stages, I will trace what information was available at the time about the Mausoleum of Halicarnassus, how and why Gian Cristoforo had this particular knowledge, and how that knowledge found its way to papal circles.

\section{Knowledge of the Mausoleum of Halicarnassus in Sixteenth-Century Rome}

The tomb of Mausolus was built by Artemisia II at Halicarnassus in the fourth century $\mathrm{BC}$ to honour her husband and brother, Mausolus of Caria. Today the site is reduced to its bare outlines, but some idea of its original appearance has come 
down to us from literary descriptions. The most complete account is found in the Natural History of Pliny the Elder:

on the north and south sides it extends for 63 feet, but the length of the facades is less, the total length of the facades and sides being $440 \mathrm{ft}$. The building rises to a height of 25 cubits and is enclosed by 36 columns. The Greek word for the surrounding colonnade is 'pteron,' 'a wing.' (...) Far above the colonnade there is a pyramid as high again as the lower structure and tapering in 24 stages to the top of its peak. At the summit there is a four-horse chariot of marble, and this was made by Pythis. The addition of this chariot rounds off the whole work and brings it to height of $140 \mathrm{ft} .{ }^{28}$

This description is important because, alongside the text of Vitruvius, Pliny was the most frequently consulted literary authority for artists, architects, and antiquarians at the centre of the Julian Renaissance in Rome. ${ }^{29}$ Vitruvius also wrote about Halicarnassus in his Ten Books of Architecture, perhaps basing his account on an actual visit there:

... this site is similar to the curvature of a theater. In the lowermost part, next to the port, the forum has been set up. At a height halfway up the slope, at the landing between the tiers of seats, so to speak, there is a street of spacious breadth, in the centre of which the Mausoleum has been made with such outstanding care that it is listed among the seven wonders of the world..$^{\circ}$

Such descriptions undoubtedly inspired Renaissance travellers to seek out Halicarnassus. But what, if any, archaeological evidence about the Mausoleum was actually available to antiquarians in the Renaissance? Travelers who visited the Aegean islands in the twelfth century describe the Mausoleum site as impressive and intact, but an earthquake in the early fourteenth century destroyed most of the structure. ${ }^{31}$ Early in the Renaissance the most famous account was given by the antiquarian Cyriacus of Ancona (1391-1452), who was inspired by Pliny's Natural History to travel the Aegean in search of monuments described there and who probably recorded his impressions of the Mausoleum. (Unfortunately, these do not exist in the surviving portions of his Commentaries. $)^{32}$ In the wake of the Plinian revival of the fifteenth century, the Mausoleum was resurrected by antiquarians who drew imaginative reconstructions based on the written accounts. A structure resembling Pliny's description appears in the Hypnerotomachia Poliphili published in Venice in 1499. A woodcut of the imagined Mausoleum, based on drawings by the architect and theorist Fra Giovanni Giocondo, was used to illustrate the first Italian translation and commentary on Vitruvius by Cesare Cesariano, printed in Milan in 1521 (Vitruvius II, 8, f.41v, see illustration 3).33 
In 1522 the Knights of St. John of Jerusalem, who resided on the island of Rhodes, plundered what remained of the Mausoleum in order to fortify their mainland stronghold, the castle of Saint Peter, which still exists today near modern-day Bodrum in Turkey. ${ }^{34}$ As we shall see, it was the presence of the Knights on the island of Rhodes, and their activities at the Mausoleum site long before 1522, that most likely brought the tomb to the attention of antiquarians and architects and perhaps inspired the design for the Julian tomb.

\section{Gian Cristoforo Romano, the Mausoleum, and Michelangelo}

The analysis of Gian Cristoforo's possible involvement in the tomb project begins by examining his intelligence about the Mausoleum. Surviving documentary evidence has long led art historians to surmise that Gian Cristoforo Romano travelled in the Levant some time before 1503. The inference has been drawn from a letter written in September 1503 by Lorenzo da Pavia, an agent for Isabella d'Este in Venice, who recommended that she buy a Hellenistic bronze statue recently arrived in Venice from the island of Rhodes (now identified as the Adorante, State Museum, Berlin). 35 Knowing that Isabella always liked the validation of an expert, Lorenzo added that the statue had been authenticated by Gian Cristoforo Romano who confirmed that he had seen it while it was in Rhodes. This statement has always been used to allude to the possibility of Gian Cristoforo's travel in the Levant; a new document now confirms this trip. On November 25, 1501 Mario Equicola wrote to the Mantua court to say that Gian Cristoforo would be in touch "when he returned from his journey to the Levant." ${ }^{36}$ Why is this important? The letter proves conclusively that Gian Cristoforo did travel to the Levant, and that the expertise about antiquities that he formed as the result of those travels led contemporaries to turn to him as an authority on Greek antiquities - an expertise that might well have been an important reason for his summons to Rome.

The earliest notice we have for Gian Cristoforo in Rome is on 30 October 1505 when Isabella wrote to him, on the eve of his departure from Bologna, to ask him to pursue some items for her from the estate of the antiquarian Giovanni Ciampolini. ${ }^{37} \mathrm{He}$ must have arrived in Rome shortly afterward. On 1 December he wrote to Isabella to inform her about various antiquities available in the city and to congratulate her on the acquisition of an antique Sleeping Cupid by Praxiteles which she had recently purchased from a Roman collection and which would serve as the pendant to the modern copy by Michelangelo that she had acquired some years before. ${ }^{38}$ Aside from these letters about antiquities, in which he reveals 
himself to be firmly ensconced in the society of key cardinals and prelates in Rome, our first notice of his other activities in Rome occurs after January of 1506, when the statue of the Laocoön was unearthed on the Esquiline Hill. As is well known, Michelangelo and Giuliano da Sangallo rushed to the site to identify the statue while it was still in the ground, and identified it on the basis of its description in the Natural History of Pliny the Elder. ${ }^{39}$

One of the first collectors outside of Rome to hear about the find was Isabella d'Este. A Mantuan agent in Rome, Ludovico Canossa, wrote on 18 January 1506 to tell her that he had discussed the new discovery with Ludovico Brognolo who was on his way to Mantua to give her a verbal account of the statue. $4^{\circ}$ The bidding for the newly-discovered group was fast and furious. On January ${ }_{11}$ Sabadino degli Arienti, a humanist with close ties to the court of Ferrara and loyal to Isabella d'Este, wrote to tell her about a letter recently received by Cardinal Raffaello Riario regarding the statue, in which it was intimated that Cardinal Galeotto Franciotti della Rovere had offered to buy it for 1000 ducats. Julius II was not inclined to sell. In fact, Sabadino offered that the owner of the vineyard where the group had been found "le tene in la sua camera apreso lo lecto ben guardate" ("keeps it in his room, close to his bed and well guarded"). ${ }^{11}$ On March 7 Canossa wrote to lament that Isabella would not have the statue to place among the treasures in her Grotta. ${ }^{42}$ On the first of June 1506, when much of the initial furor had died down, Cesare Trivulzio recorded in a letter that the statue had now been thoroughly inspected by a committee consisting of Michelangelo and Gian Cristoforo Romano, whom he called "the leading sculptors in Rome." 43 The pairing of Michelangelo and Gian Cristoforo prompts some speculation as to what they were doing together, inspecting a sculpture for Julius II.

As we have seen, Gian Cristoforo had experience in the Levant and he was an acknowledged expert on Rhodian sculpture, having authenticated the Berlin Adorante when it was in Venice; on that basis alone it seems logical that he would be called upon to examine the most famous antiquity of Rhodian manufacture that had ever been excavated in Rome. But I would also propose that the pairing of Michelangelo and Gian Cristoforo Romano can be examined in quite a different light. On a practical basis, nothing in Michelangelo's background as a sculptor had prepared him for a project like the papal tomb, which demanded the integration of over 40 life-sized sculptures into an architectural framework. Previous to 1505 his sculptural work consisted chiefly of medium-sized figures added to tombs or altars, such as that of Saint Dominic in Bologna and the Piccolomini altar in Siena, or large-scale free-standing figures like the David he had just completed in Florence, 
and the figural ensemble of his Pietà, which had made his reputation in Rome. None of these works combined figures with architecture. By the time of his summons, however, Gian Cristoforo Romano had worked on several projects that would have given him the expertise to at least consult on the Julius tomb. His contributions to the mausoleum of Giangaleazzo Visconti at the Certosa of Pavia led to other commissions, such as the tomb for Pier Francesco Trecchi in San Vincenzo, Cremona (now in the church dedicated to Sant'Agata) and the arca of the Beata Osanna Andreasi that once stood in the church of San Domenico in Mantua (destroyed in 1797); he had also been a consultant on the reliefs by the Lombardi in the chapel containing the arca of St. Anthony at the Santo in Padua. ${ }^{44}$

Of course, it is difficult to argue that Michelangelo needed any help with the tomb project; his capacity for startling invention would soon be more than evident in the Sistine ceiling. As Charles Robertson argued, however, even the conception for the ceiling, in terms of its architectural illusionism, might well have been derived from ideas that he borrowed from Bramante..$^{45}$ Although the ceiling was a triumph, the final outcome of the tomb was not nearly so positive-partly because Michelangelo was being hampered by preconceived notions that the Pope had about the design and also, as Condivi asserted, because his plans for the tomb were being frustrated by the Milanese contingent in Rome. One wonders what those frustrations were. Gian Cristoforo was certainly part of the Milanese contingent (even if by way of Mantua). Moreover, he combined knowledge of tomb design with expertise in Greek antiquity. Part of this expertise included knowledge about excavations that were being undertaken at the time at the site of the Mausoleum of Halicarnassus, knowledge derived from his acquaintance with another important Milanese figure in Rome, Fra Sabba da Castiglione.

\section{Gian Cristoforo, Fra Sabba da Castiglione, and the Mausoleum Site}

Another important figure who knew Gian Cristoforo and had direct knowledge of the Mausoleum at Halicarnassus, and who was also associated with papal circles in Rome, was the monk, antiquarian, and collector Fra Sabba da Castiglione (c.148o1554). After joining the Knights of the Order of St. John of Jerusalem, Fra Sabba was sent to their headquarters at Rhodes from 1505-8. In 1508 he was transferred from Rhodes to Rome and spent the next seven years in the service of Fabrizio del Carretto, Procurator General of the Order of the Knights of St. John in the papal city. ${ }^{46}$ Fra Sabba remained in Rome until 1516, after which he moved permanently to the Commenda at Faenza. While he was in Rome he moved in the same circles 
as Gian Cristoforo, and knew Bramante, Raphael, the Sangallo family, and Baldassare Castiglione. ${ }^{47}$ Aside from his successful ecclesiastical career, Fra Sabba is most famous for his knowledge of antiquities and his early theoretical discourse on collecting, matters he wrote about in his Ricordi, published in Venice in 1554. In this work, in his list of the best modern masters of sculpture capable of rivalling the ancients, he reserves special praise for Michelangelo and for "my Giovan Cristoforo Romano," reinforcing the link between the two as the great giants among modern masters of sculpture. ${ }^{48}$

Therefore, in 1505 and for several years afterward, at precisely the time that Gian Cristoforo was in Rome, Fra Sabba was in Rhodes, where he spent at least part of his time actively acquiring antiquities for Isabella d'Este in Mantua. In August of 1505, Fra Sabba wrote to Isabella about the mainland excavations at the Castle of St. Peter-the mainland site of the Knights, which was being rebuilt and refurbished using masonry and other salvageable materials from the nearby site of the Mausoleum of Halicarnassus. In September of 1505 he reported to Isabella that:

The Monsignor of Chiamonte, governor of Milan, has written to the Grand Master of Rhodes (Aimery d'Amboise), who is his uncle, about the fact that it has presently occurred to him in response to certain propositions that he is in great need of statues and other antiquities, and given that the island of Rhodes, and similarly at the Castle of St. Peter, and at the great sepulcher that Artemisia made for her husband, Mausolus, are places filled with such things, he has asked his Reverence if he would deign to share these with him. ${ }^{49}$

On 1 October 1506, after a journey to Jerusalem, Sabba reported that he had received a letter from the captain general of San Pietro who told him that beneath the still visible ruins of the Mausoleum complex, workers had recently unearthed an elaborately carved sepulcher which he hoped he might be able to secure for Isabella's collection. In April of 1507 he wrote to tell her that he planned to send an antique marble torso from Naxos, assuring her that its superb quality would be verified either by Mantegna or by Gian Cristoforo Romano, both of whom he knew Isabella relied on as consultants about the authenticity and quality of antiquities. In October of 1507, Fra Sabba reported that he had spoken to an engineer from Cremona (Bartolino de Castiglione) about the feasibility of transporting the sepulchre that had been found at the Mausoleum site to Mantua. ${ }^{50}$

Although the transport of the sepulchre never transpired, as the result of Fra Sabba's frequent reports to Isabella d'Este, first-hand intelligence about the Mausoleum at Halicarnassus was circulating in Mantua and beyond, to Milan and Venice, where Fra Sabba identified individual collectors, agents, and officials who 
were interested in plundering the site for available antiquities. This was especially true for Milan, since Charles D'Amboise, the governor of the city, was the brother of Aimery d'Amboise, the Grand Master of the Knights of St. John in Rhodes. In his letter of October 1507, Fra Sabba commented on the many excellent antique sculptures to be found in the garden of the Grand Master at Rhodes, and one presumes that there was a fairly active trade in antiquities between Rhodes, Venice, and Milan at this time. ${ }^{51}$

Gian Cristoforo's work as Isabella's agent in Rome, and his association with Julius II and Michelangelo, occurred virtually at the same time that Fra Sabba was in Rhodes and in touch with antiquarian circles in Milan. Giovanni Agosti has drawn needed attention to the many Milanese artists active in Rome immediately before and during the Julian Renaissance. ${ }^{52}$ While Gian Cristoforo was in Rome, he was associated with the large Milanese contingent of artists and architects that Pope Julius had brought to the city to work on St. Peter's, chiefly Bramante and the goldsmith Caradosso Foppa. The fact that so many Milanese artists were key contributors to the Julian Renaissance is significant in considering the tomb project: Milan and its environs were home to many mausolea designs besides the monument to Gian Galeazzo Visconti at the Certosa, perhaps the most significant being the designs Leonardo made for a centrally-planned mausoleum that Galeazzo Maria Sforza envisioned for Santa Maria delle Grazie (never executed).53 This general expertise concerning mausolea plans, coupled with the excitement over excavations at the Mausoleum site, must surely have had some influence on Julius's thoughts about his own tomb.

There is yet another suggestive link between the Mausoleum, Gian Cristoforo, and Milan. Gian Cristoforo is mentioned by the Milanese architectural theorist Cesare Cesariano in his Italian translation and Commentary on Vitruvius, printed in Como in 1521 but written around 1508; the same edition includes a fantastical woodcut of the Mausoleum of Halicarnassus (illustration 3). In his discussion of symmetry, which includes a woodcut of his interpretation of the Vitruvian Man, Cesariano lists Michelangelo and Gian Cristoforo Romano, as Fra Sabba did, as the most significant sculptors of the age. ${ }^{54}$ In his Lives, Vasari linked Cesariano to Sansovino and to Bramante in Rome, so he was evidently part of the same circles in which Gian Cristoforo moved and worked. ${ }^{55}$

If the suggestion is that Gian Cristoforo was instrumental in bringing knowledge of the Mausoleum to Rome, what evidence do we have for his interest in large-scale monumental architecture? While we have no autographed architectural drawings that we can attribute to Gian Cristoforo, Ceriana asserts that he arrived 
in Milan in 1491 with an album of drawings after antique architecture. ${ }^{56}$ Hubertus Gunther demonstrated that at least one sheet of drawings made by Antonio da Sangallo the Younger, now in the Uffizi, was drawn after originals by Gian Cristoforo Romano (illustration 4). On this sheet, Sangallo noted that the measurements for the depiction of the Arch of Constantine were based on calculations by Gian Cristoforo Romano, and that the measurements are recorded in Mantuan braccia rather than the more standard Venetian feet, a form of measurement that Gian Cristoforo had adopted when he was working for Isabella at the Mantuan court (and one without precedent in Sangallo's work). 57 Gunther also describes eight sheets of drawings now in the Biblioteca Nazionale in Florence (part of Codex Magliabecchiana II-I429), made by a copyist after Sangallo, one sheet of which repeats the attribution to Gian Cristoforo. He notes that the measurements on this sheet for the Arch of Constantine and for the Arch of Septimus Severus "correspond perfectly to the copies by Antonio." ${ }^{8}$ Moreover, Gunther claims that these drawings appear to have been models for later copyists and might ultimately have influenced depictions of the arches of Constantine and Septimus Severus, the Pantheon, and other Roman monuments by later artists like Serlio and Palladio. Thus, even though we possess no original drawings by Gian Cristoforo, he can be linked to the creation of measured drawings of antique monuments.

Antonio da Sangallo-who spent his career in Rome between 1515 and 1527, and then worked in other cities until his death in 1546-made many drawings after antique monuments, including a drawing of the Mausoleum of Halicarnassus (now in the Uffizi) based on the literary account and the measurements given by Pliny. 59 Although this drawing cannot be linked with any certainty to Gian Cristoforo, Sangallo's conceptualization of the Mausoleum demonstrates the sustained interest in its basic form during the period immediately after Gian Cristoforo and Fra Sabba were in Rome. Furthermore, these kinds of imaginary reconstructions of the Mausoleum had a distinct influence on tomb design over the course of the sixteenth century, particularly via the circle of Raphael and especially in Mantua. For example, when the Marchese Francesco II Gonzaga died in 1519, his son Frederico II Gonzaga asked Baldassare Castiglione to solicit both Michelangelo and Raphael for designs for his father's tomb. The drawing he received from Raphael's workshop depicted a catafalque in the form of a stepped pyramid. ${ }^{60}$ Castiglione's own monument, which can still be seen in the church of Santa Maria delle Grazie just outside Mantua, is perhaps the most complete realization of the pyramidal crowning element of the Mausoleum structure made for a Renaissance commemorative tomb (illustration 5). The tomb is actually a miniature version of the Mausoleum, a stepped pyramid 
leading up to the summit crowned with a figure of the resurrected Christ. Castiglione ordered the design from Giulio Romano on 16 September 1523, only about a year after reports that excavations at Bodrum had revealed the burial chamber, so the mausoleum was very much in the news. Giulio Romano was undoubtedly influenced by the Sangallo drawings that had circulated in Raphael's workshop in Rome, but the iterations of the form of the Mausoleum in Mantua circles might also have reflected the Mantuan connection to Rhodes and its environs that had been established by Fra Sabba da Castiglione.

\section{Some Reflections on Gian Cristoforo, Michelangelo, and the Tomb}

Based on Condivi's account, it is clear that by April of 1505 Michelangelo had planned most of the figures for the Julius tomb before he left for Carrara and disappeared for about six to eight months. ${ }^{61}$ It was precisely during this period that Gian Cristoforo arrived in Rome. Not long after, Michelangelo returned to the city and the Laocoön was discovered, which he and Gian Cristoforo inspected together at the Pope's command. It would have been easy enough, when Michelangelo was off in Carrara for all those months, for the Milanese contingent in Rome (which included Bramante, Gian Cristoforo, and Caradosso Foppa) to bend the Pope's ear about an overhaul of the tomb plan. And one of the most knowledgeable people would have been Gian Cristoforo Romano, who had practical experience in tomb design, having trained under Bregno in Rome and worked on the mausoleum of Giangaleazzo Visconti at the Certosa in Pavia. At the very least, Gian Cristoforo would have been able to offer insights into the construction of the kind of monumental free-standing architectural and sculptural ensemble that the Pope envisioned.

By May 1506 Michelangelo was back in Florence, having decided to quit the tomb and leave Rome because Julius refused to give him any more money. During this break he told Giuliano da Sangallo that he had discovered, while eavesdropping on the Pope's conversation with an unidentified jeweler (a description that could fit Caradosso or even Gian Cristoforo himself), that Julius had decided that he would not continue to finance Michelangelo's tomb project. Michelangelo also confided to Giuliano that his sudden departure had been spurred by "something else besides, which I do not want to write about" alluding to a plot against his life. ${ }^{62}$ Condivi reports that when Julius pressed him hard to return to Rome, Michelangelo entertained the idea of "going away to the Levant" to work for the sultan of Turkey who, via the mediation of certain Franciscan friars, had promised to pay him handsomely for designing a bridge from Constantinople to Pera. ${ }^{63}$ As far as I know no one has 
ever wondered why, at this particular juncture, Michelangelo might have wanted to go to Turkey. But the idea takes on greater significance if we remember that the statement was made at precisely the time that the Mausoleum of Halicarnassus was of great contemporary interest in Roman circles and knowledge about the site circulated between Gian Cristoforo Romano and his informants in Mantua and on Rhodes itself.

Gian Cristoforo Romano enjoyed great fame in his own lifetime, often paired in the contemporary literature with Michelangelo as one of the greatest sculptors of his age. Despite this reputation, Vasari mentioned him only in passing in his Lives, and from that time to the present, while scholars have largely managed to reconstruct his artistic contributions in Milan and Mantua, his time in Rome remains somewhat shrouded in mystery. ${ }^{64}$ Our understanding of Gian Cristoforo's time in Rome has undoubtedly long been overshadowed by our concentration on the major artists of the period, particularly by the image of Michelangelo: the singular, solitary, and superior genius forced to endure the tragedy of the tomb in his struggle against the lies, innuendo, and jealousies of the Bramante faction in Rome. Perhaps this is partially true, but we must take into account what modern scholarship has taught us about Michelangelo's working methods and his attitudes towards collaboration and competition. Despite how hard Condivi tries to make it seem as though Michelangelo never learned a thing from any other artist, William Wallace observed that "Michelangelo hardly ever worked alone." 65 Vasari tells us that when pressed to paint the Sistine ceiling, Michelangelo, at the Pope's suggestion, brought in a team of experienced fresco painters from Florence, only to dismiss them when he had mastered the technique himself. After the cleaning of the ceiling, William Wallace showed the clear evidence of several hands in the execution of details of the frescoes, demonstrating that Michelangelo certainly did not work alone. ${ }^{66}$ Many years ago Hanno-Walter Kruft proposed that the Sicilian sculptor Antonello Gagini contributed reliefs to the Julius tomb when he was in Rome in 1505/06, possibly working as Michelangelo's assistant on the project. ${ }^{67}$ If Gagini was involved in the project at such an early stage, then we must certainly consider the idea that other more prominent sculptors, and possibly architects and antiquarians, particularly those with expertise in tomb design and decoration, might also have made contributions.

Collaboration was not beyond the scope of Michelangelo's genius, but it seldom yielded successful results. In 1516, having taken up the Julius tomb again, Michelangelo was approached by Leo X to embellish the Medici church of San Lorenzo in Florence by creating an elaborate marble façade with several sculpted 
figures, originally in collaboration with Baccio d'Agnolo, who was to be capomaestro of the architectural portions of the program while Michelangelo carved the figures. ${ }^{68}$ Although initially agreeable, Michelangelo grew increasingly impatient with the Pope's failure to provide enough money and with what he considered to be Baccio's sophomoric and inadequate architectural vision in light of his own increasingly grandiose plans. ${ }^{69}$ Unsurprisingly, the collaboration dissolved and the façade was never built. The "failed façade" should perhaps be viewed as a sequel to the tragedy of the tomb. ${ }^{\circ}$

In Michelangelo, Drawing, and the Invention of Architecture, Cammy Brothers reminds us that "Michelangelo is too often studied in precisely the terms that he defined, rather than in the relation to the culture from which he emerged. In the case of architecture, the particular nature of Michelangelo's approach to design may be measured against the work of such contemporaries as Giuliano da Sangallo, Francesco di Giorgio, Baldassare Peruzzi, and Raphael." ${ }^{11}$ In this paper, I have urged that Gian Cristoforo Romano, who was named by many contemporaries as Michelangelo's equal among the sculptors of the age, is another figure who must have been important to the culture that shaped Michelangelo in Rome. He was certainly with Michelangelo at precisely the time that he was designing the papal tomb; at the same time, he was in touch with antiquarian culture in Milan and Mantua, and was in a position to provide knowledge, both among the Milanese artists with whom he worked and within papal circles, of activity at the site of the Mausoleum of Halicarnassus, a monument that might well have shaped Julius's ideas about his own tomb monument. At the very least, this reconsideration of Gian Cristoforo's time in Rome sheds new light on the complicated patterns of influence, collaboration, suggestion, competition, and intrigue that truly shaped the Julian Renaissance in Rome and provided the backdrop against which Michelangelo struggled with his plans for the pope's great mausoleum.

\section{Acknowledgements}

This article originated in a discussion I had at a conference of the Renaissance Society of America with Dr. Sharon Gregory (now Erasmus Chair of Renaissance Humanism at St. Francis Xavier University in Antigonish, Nova Scotia) and Allison Morgan Sherman (currently completing her PhD in Art History at the University of St. Andrew's in Scotland), regarding the possible influence of the Mausoleum of Halicarnassus on Michelangelo's design for the Julius tomb. At the time, I was working with Dr. Clifford Malcolm Brown (now retired from Carleton University) 
on a publication about Fra Sabba da Castiglione, and that work led me to think about Gian Cristoforo Romano. I thank Professor Brown for introducing me to all things Mantuan. I also sincerely thank the early and most recent readers of various drafts of this essay whose sharp criticisms, probing and pertinent questions, and keen insights were invaluable to the development of my ideas.

\section{Illustrations}

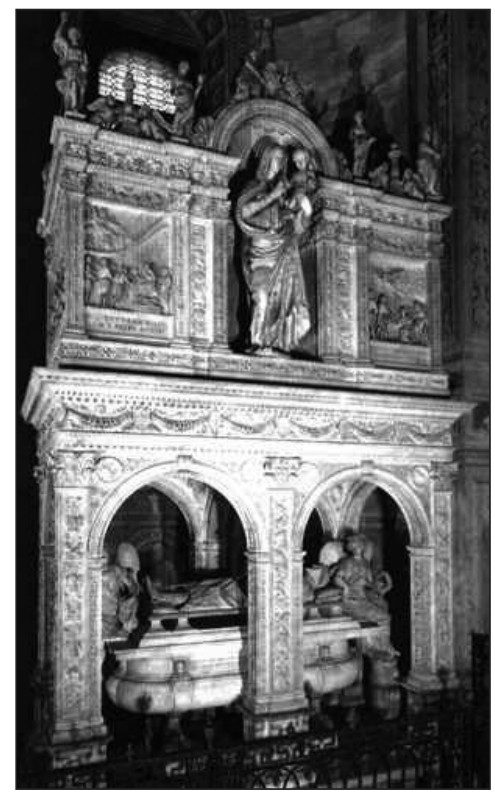

Illustration 1. Gian Cristoforo Romano and Benedetto Briosco, Monument to Gian Galeazzo Sforza, Certosa di Pavia, Pavia. Alinari/Art Resource, NY 


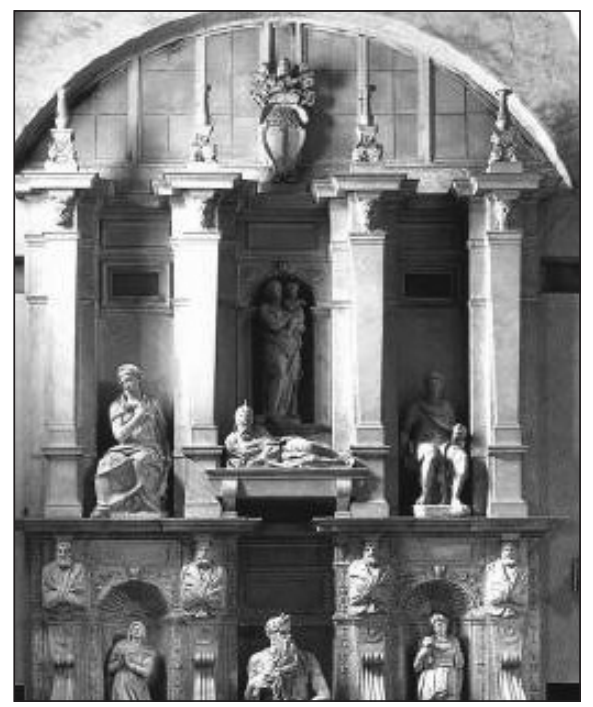

Illustration 2. Michelangelo, Tomb of Julius II, Church of San Pietro in Vincoli, Rome, c1545. Vanni/Art Resource, NY

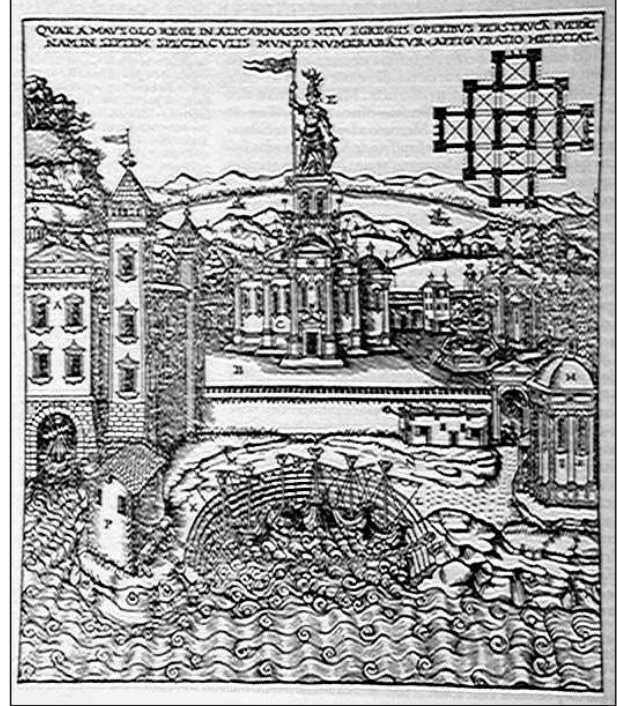

Illustration 3. Cesare Cesariano, woodcut illustration of Halicarnassus, from Commento a Vitruvio (Como: 1521), f.41v., 1521. Used with permission of the Upjohn-Waldie Collection, John W. Graham Library, Trinity College, Toronto. Photo: Author. 


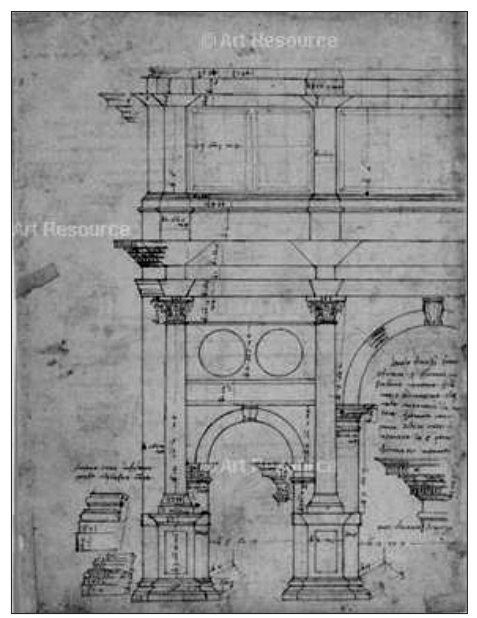

Illustration 4. Antonio da Sangallo the Younger, The Arch of Constantine at Rome, after Gian Cristoforo Romano, Gabinetto dei Disegni e delle Stampe, Uffizi, Florence. Scala/Ministero per i Beni e le Attività culturali/ Art Resource, NY

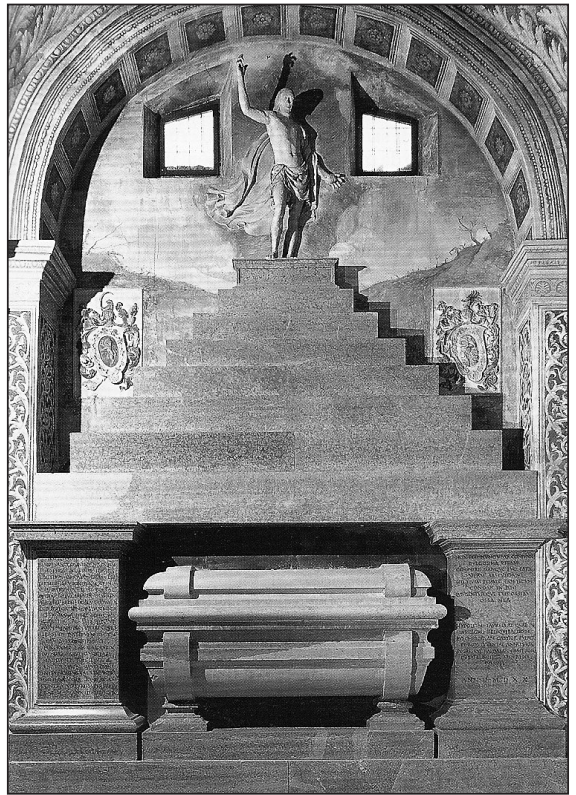

Illustration 5. Giulio Romano, tomb of Baldassare Castiglione, church of Santa Maria delle Grazie, Mantua, 1530s. Scala/Art Resource, NY. 


\section{Notes}

1. The key source for documents is still Adolfo Venturi, "Gian Cristoforo Romano," Archivio Storico dell'Arte 1 (1888), pp. 49-59, 107-18, 148-58. The July letter in which Gian Cristoforo mentions his summons to Rome is 112, n.3; further documents are provided in Kathleen Weil-Garris Brandt, The Santa Casa di Loreto: Problems in Cinquecento Sculpture (New York: Garland, 1977) and Andrea Norris, The Tomb of Gian Galeazzo Visconti at the Certosa di Pavia, Ph. D. Dissertation New York University, 1977 (Ann Arbor: 1991). For other reflections on his career see Cristina de Benedictis, "Per Gian Cristoforo Romano," Antichità Viva, 24.1-3 (Jan-June 1985), pp. 135-37, and Andrea Norris "Gian Cristoforo Romano: The Courtier as Medallist," Studies in the History of Art 21 (1987), pp. 131-41. The most recent biographical account, which does omit a few details about the artist's time in the Veneto, is M. Ceriana, “Ganti, Giovanni Cristoforo (Giancristoforo Romano),” Dizionario Bibliografico degli Italiani, v. 52 (Rome: Istituto della Enciclopedia Italiana, 1960-, 1993), pp. 203-11. A brief but excellent re-examination of his career is given by G. Romano, "Verso la maniera moderna: da Mantegna a Raffaello,” Storia dell'arte italiana 6.1 (Turin, 1981), pp. 57-63.

2. A close examination of this sojourn to Carrara is given in Michael Hirst, "Michelangelo in 1505," The Burlington Magazine 133.1064 (1991), pp. 760-66.

3. Clifford Brown and Sally Hickson, "Caradosso Foppa (ca. 1452-1526-27)," Arte Lombarda 119 (1997), pp. 9-39.

4. A full account of the Andreasi monument was most recently given by Angela Ghirardi, “Osanna Andreasi e Isabella d'Este. Tracce artistiche di un'amicizia,” in Osanna Andreasi da Mantova 1449-1505. L'immagine di una mistica del Rinascimento, ed. Renata Casarin (Mantua: Casandreasi, 2005), pp. 65-78.

5. Roberto Weiss, “The Medals of Pope Julius II (1503-1513)," Journal of the Warburg and Courtauld Institutes 28 (1965), pp. 163-82.

6. Weil-Garris Brandt, vol. 1, pp. 14-18.

7. In addition to Weiss, “The Medals of Pope Julius II," Gian Cristoforo's career in Rome is also discussed by Paolo Giordani "Studi sulla scultura Romana del Rinascimento: Gian Cristoforo Romano a Roma," l'Arte 10 (1907) and John Graham Pollard et al., Reniassance Medals: Volume One: Italy (Oxford: Oxford University Press, 2007).

8. Neither Isaia of Pisa nor Gian Cristoforo Romano are referred to in the contemporary literature by their family name, which was Ganti, see Ceriana, p. 21.

9. For Andrea Bregno see S. Maddalo, "Collezionismo antiquario e studio dell'antico nella bottega di Andrea Bregno,” Arte e documenti 3 (1989), pp. 100-9, and C. Crescentini, “'Andreas Marmorarius Sculptor Egregius,' e sua prima produzione funeraria," in Sisto IV. Le arti a Roma nel primo Rinascimento. Atti del Convegno, ed. F. Benzi and C. Crescentini (Rome: Shakespeare and Company, 200o), pp. 36283. Andrea Sansovino, who was also called by Julius II from Florence to Rome in 1505, designed the tombs of Cardinal Ascanio Sforza (d.1505) and the monument 
to Cardinal Girolamo della Rovere (d.1507), both in the choir of Santa Maria del Popolo; see Christoph Luitpold Frommel, "Giulio II e il coro di Santa Maria del Popolo,” Bolletino d'Arte (April-June 200o), pp. 1-34.

10. Sansovino also worked with the Bregno; it would be useful, in terms of the Julius tomb, to delve further into his summons to Rome, and to consider his relationship with Michelangelo. For Sansovino see George Haydn Huntley, Andrea Sansovino, Sculptor and Architect of the Italian Renaissance (Cambridge: Harvard University Press, 1935); a recent review of the documents is Andrea Sansovino: I documenti, edited by Nicoletta Baldini and Renato Giulietti (Florence: Maschietto \& Musolino, 1999).

11. For which see Andrea Norris, The Tomb of Gian Galeazzo Visconti.

12. For the Trecchi tomb, first attributed to Gian Cristoforo by Marcantonio Michiel, see Andrea Bacchi, "Da Gian Cristoforo Romano ad Alessandro Menganti: Note sulla scultura del Cinquecento a Bologna," Nuovi Studi, Rivista di arte antica e moderna, Anno I (1996), pp. 65-91, at 66-67 and ill. 138.

13. For a complete overview of Isabella's career as a collector, see Clifford M. Brown, "Per dare qualche splendore a la gloriosa cità da Mantua," Documents for the Antiquarian Collection of Isabella d'Este, with the collaboration of Anna Maria Lorenzoni and Sally Hickson (Rome: Bulzoni, 2002). For a recent re-assessment of the painted allegories made for Isabella's studiolo, Stephen J. Campbell, The Cabinet of Eros. Renaissance Mythological Painting and the Studiolo of Isabella d'Este (New Haven and London: Yale University Press, 2004).

14. For the portal, see Rodolfo Signorini, "Una 'porta gemmea.' Il portale della Grotta di Isabella d'Este in Corte Vecchia," in Per Mantova una vita. Studi in memoria di Rita Castagna, edited by Anna Maria Lorenzoni and R. Navarrini (Mantua: Publi-Paolini, 1991), pp. 25-51.

15. Gian Cristoforo's career as an antiquarian advisor in Mantua is most fully documented in the entries found in Brown, Per dare qualche splendore.

16. Baldassare Castiglione, The Courtier, translated by John Singleton (New York: Doubleday, 1959), pp. 78-79. Gian Cristoforo is also included in the sonnets written by Antonio Cammelli, popularly known as "il Pistoia"; see I sonetti faceti di Antonio Cammelli secondo l'autografo ambrosiano, ed. E. Percopò (Naples: N. Jovene, 1908) and Rime edite ed inedite di Antonio Cammelli ditto il Pistoia, ed. A. Cappelli e S. Ferrari (Livorno: Vigo, 1888). For other literary references see Giovanni Romano, "Verso la maniera moderna," p. 57.

17. There is a vast literature on the Julius tomb. For early scholarship on the tomb as originally planned in 1505 see Erwin Panofsky, “The First Two Projects of Michelangelo's Tomb of Julius II,” The Art Bulletin 19.4 (December 1937): 561-79; Charles de Tolnay, Michelangelo Vol. IV. The Tomb of Julius II. (Princeton: Princeton University Press, 1954); Paul Joannides, “A Note on the Julius Tomb 1513," The Burlington Magazine 113.816 (March 1971), pp. 148-50; Herbert von Einem, Michelangelo, trans. Ronald Taylor (London: Methuen, 1973), pp. 39-49; Christoph Frommel, "Capella Iulia: Die 
Grabkapele Papst Julius II in Neu-St. Peter,” Zeitschrift fur Kunstgeschichte XL (1977), pp. 26-62; Edith Balas, "A hypothesis on Michelangelo's 1505 project of the tomb of Julius II," Gazette des Beaux Arts, Series 6, 104 (October 1984), pp. 109-12. More recently Claudia Echinger-Maurach, Studien zu Michelangelos Juliusgrabmal, 2 vols. (Hildesheim, Zurich, New York: Georg Olms Verlag, 1991); she mentions Frommel's reference to the Mausoleum in vol. 1, pp. 422-3, making the important distinction that Condivi's description does not include the stepped pyramid that was the crowning feature of the Mausoleum at Halicarnassus.

18. For the "tragedy of the tomb" see Howard Hibbard, Michelangelo $\left(2^{\text {nd }}\right.$ ed., Boulder, Colorado: Westview Press, 1974), pp. 85-94.

19. Ascanio Condivi, Vita di Michelangelo Buonarotti (Milan: Rizzoli, 1964), pp. 40-41. For the English translation see The Life of Michelangelo by Ascanio Condivi, translated by Alice Sedgwick Wohl, ed. Hellmutt Wohl (London: Phaidon, 1976), p. 33: "And to give some idea of it, I say briefly that this tomb was to have had four faces: two were to have been eighteen braccia long to serve as the side and two of twelve as head and foot, so that came to a square and a half. All around the exterior there were niches for statues and between each niche and the next there were terms to which other statues were bound like captives, upon certain cubical bases which rose from the ground and projected outward. These represented the liberal arts, such as painting, sculpture, and architecture, each with its attributes so that it could easily be recognized for what it was, signifying thereby that all the artistic virtues were prisoners of death together with Pope Julius, so they would never find another to favor and foster them as he did. Above these statues ran a cornice which bound the whole work together, on which level there were four large statues, one of which, namely the Moses, appears in S. Pietro in Vincoli; and this will be discussed in its proper place. Continuing upward, the work terminated in a surface upon which there were two angels supporting a sarcophagus: one of them seemed to smile as if rejoicing that the soul of the pope had been received among the blessed spirits, the other to weep as if grieving that the world should be stripped of such a man. Through one end, the one which was at the upper side, one entered into a small chamber within the tomb resembling a tempietto, in the center of which was a marble chest where the body of the pope was to be placed."

20. Metropolitan Museum of Art, New York, inv. 62.93.1, Michael Hirst, Michelangelo and His Drawings (New Haven and London: Yale University Press, 1989), pp. 81-82 and plate 173 .

21. Cammy Brothers, Michelangelo, Drawing, and the Invention of Architecture (New Haven and London: Yale University Press, 2008) agrees with Hirst's evalution of the drawing, which she also reproduces as illustration 121, p. 88.

22. Brothers, in Michelangelo, offers the clearest analysis of the existing drawings in terms of the evolution of the tomb from the 1505 plan to the one in 1513 . For the 1513 plan, by Giacomo Rocchetti, copy of Michelangelo's 1513 design for the tomb of Julius II, pen and ink, wash, Kupferstichkabinett, Staatliche Museen zu Berlin, inv. KdZ 15306, see 
her illustration 144, 103; for the drawing in the Uffizi, inv. 608Er, see illustration 145, 104. For her analysis of how the tomb developed through the drawings, pp. 87-91 and 102-4. There are also sketches on a sheet in the Ashmolean Museum which could be preparatory studies for the slaves, but which do nothing to elucidate the original plan for the tomb; see Paul Joannides, The Drawings of Michelangelo and His Followers in the Ashmolean Museum (Cambridge: Cambridge University Press, 2007), pp. 120-6.

23. Brothers, pp. 104-5.

24. Brothers uses the term "compromised," p. 87.

25. Alfred Frazer, “A Numismatic Source for Michelangelo’s First Design for the Tomb of Julius II," The Art Bulletin 57.1 (March 1975), pp. 53-57.

26. von Einem, p. 44; Christoph Frommel, "Giulio II e il Coro di Santa Maria del Popolo," Bolletino d'Arte 85.112 (2000), pp. 1-78; Brothers also cites the Rucellai Chapel and the Sforza monument as important precedents to the Julian tomb (p. 87).

27. Frommel, “Capella Iulia," p. 38.

28. Pliny. Natural History, with an English translation by H. Rackham, Loeb Classical Library, 10 vols. (Cambridge: Harvard University Press, 1956-), vol. 10, Book 36, pp. iv, pp. 30-32, at p. 23 and p. 25. See Rackham's comments on how to interpret the measurements given by Pliny. John Bury, "Chapter III of the Hypnerotomachia Poliphili and the Tomb of Mausolus," Word \& Image 14.1-2 (January/June 1998), pp. 40-60, also discusses Pliny's measurements.

29. For an exploration of the importance of Pliny's text to antiquarians eager to identify and codify their antiquarian finds in Rome, see Michael Koortbojian, "Pliny's Laocoön?” in Antiquity and Its Interpreters, eds. Alina Payne, Ann Kuttner, Rebekah Smick (Cambridge: Cambridge University Press, 2000), pp. 199-216.

30. Vitruvius. Ten Books on Architecture, trans. Ingrid D. Rowland, commentary and illustrations by Thomas Noble Howe (New York: Cambridge University Press, 1999), Book 2.8, at pp. 40-41; for the possibility that Vitruvius visited Halicarnassus see the Introduction to this translation at p. 6.

31. The archaeological history of the site is reviewed briefly in Sandro de Maria and Simone Rambaldi, "Sabba da Castiglione e gli albori dell'archeologia greca," in Sabba da Castiglione 1480-1554, Dalle corte rinascimentali alla Commenda di Faenza, Atti del Convegno, Faenza, 19-20 maggio 2000, ed. Anna Rosa Gentilini (Florence, Olschki, 2004), pp. 329-56.

32. For Cyriacus, see Edward W. Bodnar, Cyriacus of Ancona and Athens (Brussels: Latomus, 1960) and Phyllis W. Lehmann, Samothracian Reflections: Aspects of the Revival of the Antique (Princeton: Princeton University Press, 1973). For a summary of his activities within the broader scope of contemporary antiquarian culture, see Patricia Fortini Brown, Venice \& Antiquity: The Venetian Sense of the Past (New Haven and London: Yale University Press, 1996), pp. 81-91. Bury suggests that Cyriacus might well have transmitted knowledge about the Mausoleum in his diaries or Commentarii, which survive only in incomplete copies (p. 50). 
33. For the Cesariano woodcut of the Mausoleum site, see Vitruvio De Architectura, Translato e commento et affigurato da Caesare Caesariano 1521, Arnoldo Bruschi, Adriano Carugo e Francesco Paolo Fiore, eds. (Milan: Edizioni Il Polifilo, 1981), f.41v; for some insight into Cesariano's sources for his illustrations, see the Introduction to this volume by Arnaldo Bruschi, pp. lxv-lxxviii. It would be interesting to know if any of these reconstructions were influenced by the second-century Roman tomb that still survives at Milas (now Gümüşkesen), thought to be based on the design of the Mausoleum; see John Freely, Classical Turkey (San Francisco: Chronicle Books, 1990), pp. 96-97. This tomb is mentioned briefly in connection to the nineteenthcentury reconstruction in Bury, p. 46. The most comprehensive synthesis of the influence of the Mausoleum in the Renaissance is in The Maussolleion at Halikarnassos. Report of the Danish Archaeological Expedition to Bodrum, Pul Pedersen and Kristian Jeppesen, eds., vol. 2, part 2: Anthony Luttrell, The Later History of the Maussolleion and its Utilization in the Hospitaller Castle at Bodrum (Copenhagen: Distributed through Aarhus University Press, 1986), pp. 114-214.

34. Luttrell, p. 177.

35. When it arrived in Venice, the statue was first purchased by the jeweller Giovanni Andrea da Fiore but then went to the collector Andrea Martini, a member of the Knights of St. John of Jerusalem. For its history see Irene Favaretto, Arte antica e cultura antiquaria nelle collezioni venete al tempo della Serenissima (Rome: "L'Erma" di Bretschneider, 1990), pp. 124-25; see also Marilyn Perry, "A Greek Bronze in Renaissance Venice,” The Burlington Magazine 117 (1975), pp. 204-11. For the letter of Lorenzo di Pavia, see Brown, Per dare qualche splendore, pp. 176-77.

36. ASM, b.283, Mario Equicola in Blois to Margherita Cantelma in Mantua, 25 November 1501: “... Dell'andata de Ioan Christofano nostro in Levante ne piglio dispiacere per non essere la conditione de' tempi tale che da quelle part posa reportare né honore né utile et li periculi sì terrestri sì maritimi essere evidenti et grandissimi. Questa sua così inopinata partita certo ho la casuata desperatione dede amore overo extrema pazia: qual sia da queste quella il iudiche, cognoscendo lui como mi el cognosco." I wish to thank Anna Maria Lorenzoni, now retired from the Archivio di Stato in Mantua, for checking this transcription for me.

37. Brown, Per dare qualche splendore, pp. 212-14.

38. For the Sleeping Cupids see Brown, Per dare qualche splendore, pp. 111-12, 160-72 and 352-56.

39. The story of the Laocoön is famous and repeated in virtually every source on Michelangelo; the main documents are summarized by Giovanni Poggi in Il Carteggio di Michelangelo, eds. Paola Barocchi and Renzo Ristori, vol. 1 of 7 vols. (Florence: Sansoni, 1965), pp.359-6o. A synopsis of the discovery of the Laocoön and an incisive analysis of the meaning of the work in the context of antiquarian culture in the Renaissance is found in Leonard Barkan, Unearthing the Past: Archaeology and Aesthetics in the Making of Renaissance Culture (New Haven: Yale University Press, 1999), pp. 2-17. Any modern account of the Laocoön must take into consideration 
Lynn Catterson's argument that the statue might have been Michelangelo's most successful forgery, for which see her "Michelangelo's 'Laocoön?,' Artibus et Historiae 26.52 (2005), pp. 29-56. The most obvious argument against this hypothesis is the fact that such a ruse would have required a number of conspirators to be successful, among them Gian Cristoforo Romano who later inspected the statue with Michelangelo at the request of Julius II (see below).

40. Brown, Per dare qualche splendore, pp. 216-18.

41. Sabadino concludes his letter to Isabella of 31 January saying: "El cardinale San Piero ad Vincula glie ne ha voluto dare mille ducati [for the Laocoön], monsignor nostro reverendissimo le voleva, el papa gli ha decto che non ne facia contracto alchuno che lui le vole. Tutta Roma die noctuque concorre a quella casa che lì pare el iubileo. La magiore parte de li cardinali li sono iti ad vedere. Lui le tene in la sua camera apresso lo lecto ben guardate." Ibid., 217-8. An English translation of the letter is found in Koortbojian, p. 200, but he gives the date as 15 January.

42. Brown, Per dare qualche splendore, p. 218.

43. This part of Trivulzio's letter is found in English translation in Barkan, p. 112. They were asked to assess whether, as Pliny reported, the statue was made of a single block. Their inspection determined that there were four joins in the marble.

44. For Gian Cristoforo's work as an appraiser of Antonio Lombardo's relief of the Miracle of the Speaking Babe in Padua, see Anne Markham Schulz, Giambattista and Lorenzo Bregno. Venetian Sculpture in the High Renaissance (Cambridge: Cambridge University Press, 1991), pp. 106-7. This reference seems to have been overlooked in the general literature about Gian Cristoforo, but is important evidence of his activities in Venice and the Veneto.

45. Charles Robertson, "Bramante, Michelangelo and the Sistine Ceiling," Journal of the Warburg and Courtauld Institutes 49 (1986), pp. 91-105.

46. I due testamenti di Fra Sabba da Castiglione, ed. Santa Cortese (Ravenna: Stefano Casanova Editore, 2000), p. xiii. In his correspondence with Isabella, Fra Sabba actively sought a post with Sixtus Gara della Rovere, a nephew of Julius II in Rome who became Vice-Chancellor of the church and occupied the Palazzo della Cancelleria from 1508 until his death in 1517 , but Isabella was unable to secure this for him; see Brown and Hickson, "Sabba ed Isabella d'Este Gonzaga," in Sabba da Castiglione, p. 290.

47. Luttrell, p. 177. See also Rodolfo Signorini, "Gonzaga Tombs and Catafalques," in Splendours of the Gonzaga, eds. David Chambers and Jane Martineau (London: Victoria \& Alberti, 1981), pp. 3-14. A drawing of the catafalque in the Archivio di Stato in Mantua is given at p. 4; a drawing attributed to Alfonso Cittadella of a tomb similar to this catafalque, which was projected but never built, is found at p. 11.

48. In Fra Sabba da Castiglione, Riccordi ovvero ammaestramenti, a cura di Santa Cortesi (Faenza: Stefano Casanova Editore, 1999), Ricordo 109, "Circa gli ornamenti della casa," "E chi le adorna con le opera del mio Giovan Cristoforo Romano, il quale, oltra le altre virtù e massimamente la musica, fu al suo tempo scultore eccellente e famoso 
e molto delicato e diligente, cone si vede per molti lavori di sua mano in Milano e in Mantoa e massimamente per la nobile e ingegnosa sepoltura di Galeazzo Visconti nella Certosa di Pavia. E se non che nella età su più verde e più fiorita fu assalito d'incurabile infermità forse tra li due primi stato sarebbe il terzo," meaning he would place him next to Michelangelo and Apelles, pp.160-1. For the most recent studies of Fra Sabba da Castiglione see the essays in Sabba da Castiglione 1480-1554, Dalle corte rinascimentali alla Commenda di Faenza, Atti del Convegno, Faenza, 19-20 maggio 2000, ed. Anna Rosa Gentilini (Florence, Olschki, 2004); for an examination of his Ricordi, see Antonietta Paolillo, Fra Sabba da Castiglione. Antiquario e Teorico del collezionismo nella Faenza del 1500 (Faenza: Stefano Casanova Editore, 2000).

49. "Monsignore de Chiamonte, governatore de Milano, scriva al reverendissimo monsignore gran mastro de Rhode (Aimery d'Amboise), suo ció sive barba, come al presente glie acade a certi soi prepositi de havere bisogno grandissimo de statue et altre antiquitati, et per esser l'insola de Rhode, et parimenti quello de lango et Castello Santo Pietro, over gli e la sepultura che fece Artimisia a Mausoleo, suo marito, luogi copisi de queste cose, suplica a la sua signoria reverendissima che quella se degni di fargline parte," (ASM, b.799), in Clifford M. Brown and Sally Hickson, "Sabba da Castiglione ed Isabella d'Este Gonzaga. Fra Rodi e Mantova,” pp. 195-97; see the checklist of documents concerning Fra Sabba's period in Rhodes at pp. 193-312.

50. Rhodes, pp. 169 and 181.

51. For antiquarians in Milan see Giovanni Agosti, Bambaia e il classicismo a Roma (Turin: Einaudi, 1990), pp. 47-68; he discusses Gian Giacomo Trivulzio, Giovanni Francesco Marliano, and the rich collection of gems and miniature bronzes left as part of the estate of Giovanni Sforza of Pesaro, acquired by Isabella d'Este after long negotiations in 1515 (pp. 66-67). For these negotiations see Brown, Per dare qualche splendore, pp. 266-73.

52. Agosti, Bambaia, pp. 68-102.

53. For some insights into mausolea in Milan see Sabina Eiche and G. Lubkin, "The Mausoleum Plan of Galeazzo Maria Sforza," Mitteilungen des Kunsthistorischen Institutes in Florenz 22 (1988), pp. 547-53. For Leonardo's possible drawing of the Sforza mausoleum plan (in the Ashburnham Codes) see Martin Kemp, Leonardo da Vinci: The Marvelous Works of Nature and Man (Oxford: Oxford University Press, 2006), p. 90. In the Lombard context, there is also the example of the funerary chapel of Bartolomeo Colleoni in Bergamo; see Giles Knox, “The Colleoni Chapel in Bergamo and the politics of urban space," Journal of the Society of Architectural Historians 60.3 (September 2001), pp. 290-309.

54. “... hano con epse symmetrie immitate da le bone stature operato cose che quasi de alcuni Italiani pono essere a la comparatione de epsi antiqui: Si como Michele Angelo Fiorentino: Ioanne Christoforo Romano, Il nostro Christoforo dicto il Gobo: \& Augustino Busto Mediolensi: Tullio Lombardo in Venetia: Bartholameo Clemento in Regio di Lombardi: \& molti altri che floreno per le loro opere in Italia sono digni di essere comendati con maxime laude," in Cesariano, Commento 
a Vitruvio, f.xlviIIv; the reference to Gian Cristoforo was mentioned by Julius Schlosser Magnino, La letteratura artistica: Manuale delle fonti della storia dell'arte moderna, trans. Filippo Rossi (Florence: La Nuova Italia, 1964), p. 252. For an analysis of Cesariano's commentary in the context of works dedicated to Lombard artists in this period, see Giovanni Agosti, "Scrittori che parlano di artisti, tra Quattro e Cinquecento in Lombardia,” in Quattro Pezzi Lombardi (per Maria Teresa Binaghi), eds. Barbara Agosti, Giovanni Agosti, Carl Brandon Strehlke and Marco Tanzi (Edizioni l'Obliquo, 1998), pp. 39-93.

55. Giorgio Vasari, Lives of the most eminent painters, sculptors and architects etc., trans. Gaston de Vere, 10 vols. (London: MacMillan \& Co., 1912-5), vol. 9, p. 190.

56. Ceriana, p. 206

57. Hubertus Gunther, "Méthodes scientifiques modernes et archeologues de la renaissance, études inconnues to Gian Cristoforo Romano," in Archives et histoire de l'architecture: Actes du colloque des 5, 6, et 7 mai 1988 a Paris, ed. Pierre Joly (Paris: Villette, 1990), pp. 212-42.

58. Gunther, pp. 225-26.

59. The drawing, "Florence, Uffizi, Gabinetto dei Disegni e delle Stampe UA1037," is reproduced by Frommel, "Cappella Iulia," p. 38; see also Echinger-Maurach, Michelangelos Juliusgrabmal, vol. 1, pp. 422-23. In Architectural Drawings of Antonio da Sangallo the Younger, vol. 1, Fortifications, Machines and Festival Architecture, eds. Christoph L. Frommel and Nicholas Adams (New York: Architectural History Foundation 1994), there is a description of another sheet, U857A, recto, "Studies of the volume of a pyramid (possibly related to the reconstruction of the Mausoleum of Halicarnassus or duplication of squares described in Vitruvius," before 1530 (p. 158).

6o. For the catafalque for Francesco II Gonzaga, Rodolfo Signorini, "Gonzaga Tombs and Catafalques," in Splendours of the Gonzaga, eds. David Chambers and Jane Martineau (London: Victoria \& Albert Museum, 1981), pp. 3-13, the drawing is illustration 7, "Catafalque of Marchese Francesco Gonzaga," Asmagb. 85 reg. 10c 125r. These monuments are also discussed by Luttrell, p. 177; Frommel, "Cappella Iulia," p. 42, and Echinger-Maurach, vol. 1, p. 423. For more reflections on the influence of the Mausoleum on Mantuan tomb monuments, see de Maria and Rambaldi, "Sabba da Castiglione e gli albori dell'archeologia Greca," in Sabba da Castiglione, pp. 329- 56.

61. See Hirst's re-examination of the documents for Michelangelo's time in Carrara, "Michelangelo in 1505," pp. 760-66.

62. Il Carteggio di Michelangelo, Barocchi and Ristori, viII, 13, Michelangelo in Firenze a Giuliano da Sangallo in Roma, 2 maggio 1506, sabato: "Della partita mia, egli è vero che io udi' dire el Sabato Santo al Papa, parlando chon uno g[i]oelliere. a.catavola, e chol maestro delle cerimonie, che non voleva spendere più uno baiocho né in pietre pichole né in grosse: ond'io ne presi amiratione assai; pure, inanzi che io mi partissi, gli domandai parte del bixognio mio per seguire l'opera." He adds later "Ma questa solo non fu cagione interamente della mia partita, ma fu pure altra cosa, la quale non voglio scrivere; basta ch'ella mi fe' pensare, s'i' stavo a.rRoma, che fussi facta 
prima la sepultura mia che quella del Papa. E questa fu chagione della mia partita sùbita." Paul Barolsky investigates the various explanations Michelangelo invented over the years as to why he felt compelled to leave Rome at this time, in The Faun in the Garden. Michelangelo and the Poetic Origins of Italian Renaissance Art (University Park: Pennsylvania State University Press, 1994), pp. 120-28.

63. Condivi, Life of Michelangelo (Wohl trans.), p. 37.

64. "A pupil of Paolo [Romano] was the Roman Gian Cristoforo, who was an able sculptor: and there are certain works by his hand in S. Maria Trastevere and in other places,"Vasari, Lives (deVere translation), vol. 3, ch. 54, 92

65. William Wallace, Michelangelo at San Lorenzo: The Genius as Entrepreneur (Cambridge: Cambridge University Press, 1994), p. 4. For more reflections on Michelangelo's dependence on other artists, see Robertson, pp. 91-105.

66. See William Wallace, "Michelangelo's Assistants in the Sistine Chapel," in The Sistine Chapel (Michelangelo: Selected Scholarship in English). (London: Routledge, 1995), pp. 327-40.

67. Hanno-Walter Kruft, "Antonello Gagini as Co-Author with Michelangelo on the Tomb of Pope Julius II," The Burlington Magazine 117.870 (September 1975), pp. 59899 and 601.

68. On Baccio as collaborator see Wallace, Michelangelo at San Lorenzo, particularly pp. 9-12.

69. He actually called Baccio's model for the façade "childish"; see Rona Goffen, Renaissance Rivals. Michelangelo, Leonardo, Raphael, Titian (New Haven \& London, 2002), p. 243.

70. The expression is used by Wallace to characterize the façade project, in Michelangelo at San Lorenzo, p. 17.

71. Brothers, Michelangelo, p. 48. 